\title{
Anarchist Readings of Spinoza
}

\section{Daniel Colson}

The interest in Spinoza during the last third of the previous century was not merely academic, and for the most part it diverged sharply from the rationalist and idealist interpretations of Spinoza that, at least in France, had long managed to neutralize a thought too sulfurous to find a place in the official edifice of philosophy.* The originality of this reevaluation lies in its doubly political character: in its content, as we shall see; but also in its raisons d'être and in the significance it assumes as we enter into a new century.

Kant or Spinoza. One could say that these two philosophers served as flags for an entire generation of philosophers and intellectuals who were caught up by the vast movement of rebellion in the sixties and seventies and who, after the winters of reaction and the failure of Marxism, had to convert to surer ideals. Most of them, anxious to forget the harshness and cynicism of the times by hiding behind the moderate values and pretenses of democracy and humanism, turned to Kant. ${ }^{1}$ Others turned to Spinoza - the orphaned and disconsolate Marxists who, anxious to preserve the revolutionary ideals of their youth and in any case accustomed to other disasters, joined the thin ranks of the Spinozists and Nietzscheans.

By invoking various possible libertarian readings of Spinoza, the study that follows has a limited aim: to give an account of how the principal anarchist theorists comprehended Spinoza. In a provisional way, it will explore a dimly-sensed possibility: the possibility of an

*This essay originally appeared as "Lectures anarchistes de Spinoza," Rétractions 2 (Summer 1998): 119-148. It was reprinted on R.A. Forum (http://raforum.info). We thank the author for permission to translate it here. 
encounter between anarchism and Spinozism, both from the viewpoint of the libertarian side, as well as from the viewpoint of the Spinozists least inclined to make the effort to read anarchist authors and texts.

\section{Bakunin and Proudhon}

Bakunin, presumably, never had the time or the will to read Spinoza directly or thoroughly. He knows the philosopher, however. Soemtimes he quotes him, and his most philosophical texts are not without a trace of Spinoza's influence. In Bakunin, we can discern at least two understandings of Spinoza.

First, there is a youthful understanding, derived primarily from the early philosophy of Schelling, ${ }^{2}$ who, in a diffuse way, never ceased to inspire Bakunin's thought, as evidenced by the concept of freedom that Bakunin demands, ${ }^{3}$ his constant denunciation of free will, and especially his materialist conception of nature and the world.

"Nature is the sum of actual transformations of things that are and will be ceaselessly produced within its womb....Call it, if you find it amusing, God, the Absolute- it really does not matter-provided you do not attribute to the word God a meaning different from the one we have just established: the universal, natural, necessary, and real, but in no way predetermined, preconceived, or foreknown combination of the infinity of particular actions and reactions which all things having real existence constantly exercise upon one another."

The second reference, no doubt influenced by the reading of Proudhon, is late, explicit, and strongly critical. For Bakunin, Spinoza, despite his pantheism, does not escape the illusions of all those-and they are numerous - who claim to consider everything from the "point of view of the absolute, or, as Spinoza said, sub specie aeternitatis," thus relegating man to the nothingness of his "relative" existence. ${ }^{5}$

They begin with God, either as a person or as divine substance or idea, and the first step that they take is a terrible fall from the sublime heights of the eternal ideal into the mire of the material world; from absolute perfection into absolute imperfection; from thought to being, or rather, from supreme being to nothing. ${ }^{6}$

Deus sive natura, God or nature. For Bakunin, there would therefore be two possible readings of Spinoza:

On the one hand, there is Spinoza the theologian — certainly of an unusual sort, but a theologian nevertheless - for whom God is identified with nature, with substance, but always with the form of a 


\section{DANIEL COLSON}

transcendent first principle, the absolute and infinite cause of an infinity of finite beings, irremediably relegated to the nothingness of their finitude.

On the other hand, there is an atheist Spinoza, the silent inspiration, via Schelling and Diderot, of a conception of nature in the form of a "universal, natural, necessary, and real, but in no way predetermined, preconceived, or foreknown combination" of an "infinity of particular actions and reactions which all things having real existence constantly exercise upon one another"-a nature for which it matters little if it is called God or the absolute.

In this double and contradictory understanding of Spinoza, we can thus see that Bakunin anticipates the ambiguity of contemporary interpretations of this philosopher, and especially of interpretations of the famous formula of the Ethics, Deus sive natura.

- God/or/nature: does this amount to two equivalent definitions of the same reality: substance, the infinite, absolute, remote and vertical cause of all that exists? ${ }^{7}$

- God/that-is-to-say/nature; is the concept of God not, on the contrary, only the conventional starting point of a thought process which transforms it into something else, into a new perception of our world? A radically immanent world, in which the efficient cause of the Scholastics transforms into self-causation, ${ }^{8}$ in which, as Bakunin wished, necessity can finally be transformed into true freedom.?

Deus sive natura, God/or/nature. Beyond the words, it is indeed necessary to choose, through a third possible translation of the famous formula of Spinoza, a resolutely disjunctive translation, certainly an erroneous one, but one which, paradoxically, may provide the meaning of Spinoza's choices in the face of Descartes and the thought of his time, the choices and the engagement underlying the current interest in his texts and the meaning they can have for us. ${ }^{10}$

For a long time, Proudhon was unaware of Spinoza. His reading journals, carefully indexed from 1838 to 1844, never mention him. He is absent from The Creation of Order In Humanity (published in 1843), although this book devotes two major sections to philosophy and metaphysics. With the exception of a few passing allusions in the System of Economic Contradictions, it would take Proudhon until 1858, in his great work on Justice in the Revolution and in the Church, to finally engage in a critique of Spinoza: to bring together the two thoughts, and thus 
to place them in opposition, to the best of his ability, in a way which expresses a direct, attentive reading of the texts. Quoted several times, Spinoza is the subject of three critical developments: in the fourth study, concerning the problem of the State; in the seventh, with respect to the Absolute; in the eighth, with respect to consciousness and freedom.

Of these three critiques, the first is certainly the quickest and most severe. Proudhon places Spinoza beside Plato and Hegel, on the side of despotism. ${ }^{11}$ As a "saint of philosophy," persecuted by all the religious establishments, Spinoza knew, as did Machiavelli and Hobbes, how to free himself from the delusions and domination of religion. ${ }^{12}$ But "in forgetting the Gospel" he was satisfied to "relearn destiny," the fatum of the Ancients, Plato's raison d'État. ${ }^{13}$ Necessity and reason: such is the insupportable conceptual couple reinvented by Machiavelli, Hobbes, and Spinoza — a couple that justifies the "most appalling despotism." ${ }^{\prime 14}$ Indeed, because the State is governed by the principle of necessity, it is immune to any judgment, any distinction between good and evil. It "has the right to govern, by violence if necessary, and to send citizens to their deaths for the slightest causes."15 "Balanced" only by the hypothetical prudence of the sovereign in the face of a possible revolt of the governed, the governmental forms, long monarchical or aristocratic, become democratic in vain, they never cease to serve the raison d'État with political reason. ${ }^{16}$

The second critique no longer targets Spinoza's political works, but his Ethics, his major philosophical work. One could summarize it by this formula of Proudhon's: "Spinoza...begins...with an act of faith in the absolute." ${ }^{, 17}$ Here again we find Bakunin's critique anticipated. As with most philosophers, Spinoza's error is in his starting point. The absolute, a "principle of illusion and of charlatanism," can easily be "incarnated in the person,... in the race, in the city, the corporation, the State, the Church," and it inevitably leads to God. ${ }^{18}$ That Spinoza, in his Ethics, begins directly with God is thus a credit to his extreme rigor, but it is the rigor of a "great mind perverted by the absolute." 19

This error at the origin is not only philosophical. For Proudhon it is directly at the root of Spinoza's political conceptions, of his inevitable celebration of despotism and raison d'État. Indeed, in the face of the absolute, infinite being, what can man do from his position of finitude, enslaved by his passions? Nothing, if not to subject himself to "an iron discipline organized on the double principle of theological reason and raison d'État." 20 


\section{DANIEL COLSON}

Spinoza, who believed that he was forging the ethics of humanity, has reinvented, in more geometrico, the ethics of the supreme Being, i.e., the system of political and religious tyranny under which humanity has lived for sixty centuries. He was accused of atheism: he is the most profound of theologians. $^{21}$

The third and perhaps most debatable critique is at the same time the most interesting one, for three reasons: (1) because in tackling the question of freedom, it is at the heart of the Spinozist problem, the problem of the necessity-freedom couple; (2) because, in thinking that he has detected a contradiction in Spinoza's system, Proudhon opens up, in his eyes, a flaw in this system, in the necessary (and thus despotic) sequence of its developments; (3) because, in so doing, Proudhon is led to clarify a whole dimension of his own conceptions of freedom and, perhaps, the links between these and Spinozism.

Let us recall the essence of Proudhon's thesis. Faithful to his practice of paradox and antagonism, Proudhon attempts to demonstrate: (1) how Descartes, favoring free will, constructs a theory that leads to its negation; (2) how Spinoza, a denier of free will, proposes, on the contrary, a theory that necessarily presupposes it. ${ }^{22}$

Descartes is a philosopher of despotism, Spinoza is a philosopher of freedom. Over and above the interest that such a thesis might have for an anarchist's ear, and before even considering the force of Proudhon's insight, one can initially be surprised only by his glaring inconsistency. Can Spinoza, the philosopher of the absolute, of necessity and raison d'État, who, quite logically, denies that free will has any meaning, be at the same time the philosopher of freedom, a freedom inherent in his system? Drawn by his taste for provocation, Proudhon is led to develop a paradoxical argument.

Spinoza is only the enemy of free will because he is, in the first place, a consistent Cartesian. In affirming with Descartes the absolute necessity of Being (God), Spinoza allows himself to demonstrate the inconsistency of a thought that also asserts freedom, since such a system excludes any freedom apart from that of God himself. ${ }^{23}$ But this inconsistency which Spinoza reveals at the origin of Descartes' system can also be found, reversed, in the philosophy of Spinoza, this time under Proudhon's inspection. How can Spinoza deny free will, since, in the Ethics, he intends to show how the human being, the degraded and miserable creation of the all-powerful divine, subject 
to the fogs and mirages of the passions, can despite everything "push back against the tide of necessity" that produced it, freeing itself from the passions that ensnare and mislead it, in order to attain a "freedom at the expense of the necessity to which it is subordinated"?24

It must be seen to be believed; and how can Spinoza's translators and critics fail to see it? The Etbics, which everyone knows as a theory of necessity in God, is at the same time a theory of man's free will. This word is left unstated, and it is right to say that the author does not believe in it at all; but since when does one judge a philosopher exclusively on his words? $?^{25}$

One is undoubtedly closer here to Proudhon's insight, the insight that Spinoza can say something other than what he seems to say to his nineteenth century readers; the insight of another significance of Spinozism, masked by the "system of Descartes" and by two centuries of more or less blind translations and criticisms; a significance which appears only to the half-perspicacious eye of Proudhon in the form of a contradiction - a contradiction in Spinoza, but also a contradiction (or hesitation) in Proudhon himself. Indeed, in his demonstrative and rhetorical ardor, Proudhon does not manage to omit from his sentences the ambivalence that suddenly takes hold of him. Is the assertion of freedom (free will) that he believes he detects in Spinoza a mere contradiction in his system, or, on the contrary, its necessary consequence, as he says later on? ${ }^{26}$ Is Spinoza merely a disciple of Descartes, an intransigent and rigorous disciple who would take his Master's system to its extreme conclusions, or, quite to the contrary, the ingenious inventor of a new theory, of an "unparalelled originality"? ${ }^{27}$

"Since when does one exclusively judge a philosopher on his words?" One sees more clearly, a hundred and fifty years later, the great difficulty in which Proudhon found himself while trying to clarify his insight. To do this, he would have had to return to the Latin text and give Spinoza an attention and a kind of personal disinterestedness which were neither in his temperament nor his habits. In particular, he would have had to go beyond his critique of the translators and the critics of his time, for in spite of the acuity of his gaze and his own bloodhound or hunting-dog instincts, he was indeed doubly a prisoner of this translation and this criticism: a prisoner of E. Saisset's particularly calamitous text; ${ }^{28}$ a prisoner of a French interpretation of Spinoza 


\section{DANIEL COLSON}

anxious to reduce him to a mere continuation of Descartes, a celebrant of the absolute, an unrepentant rationalist and idealist, a pure logician, enemy of all experiment [expérience], of any experimental direction. ${ }^{29}$

"Soul" for mens, "passions" for affectus, "general" for commune, etc.: how, with such a translation, could Proudhon have failed to make an idealistic and Christian reading of a text which, written in Latin, takes good care to use the vocabulary and categories of the thought of its time? Under Saisset's misleading pen and Proudhon's apprehensive gaze, Spinoza not only appears as an heir to the Christian gnosis and its metaphysical theory of the Fall and Redemption; ${ }^{30}$ his thought seems to fit naturally with a catharsis and a dualism which are equally traditional-freedom against necessity, knowledge opposed to the passions of the body, the soul as a spiritual principle of salvation and freedom. ${ }^{31}$

It is here, however, even within his incomprehension of Spinoza, that Proudhon's analysis is most interesting, for the question that it poses to him, and for the answer this question suggests:

I thus ask Spinoza: if everything comes from divine necessity, following which the increasingly weakened vibrations of this necessity gave rise to souls locked in bondage to the passions, how can it come about that these souls should find, by means of their adequate ideas, more power to return to God than they ever received from the moment of their existence, if they are not in themselves free forces? $?^{32}$

Free forces, free will: undoubtedly Bakunin is not entirely wrong to reproach Proudhon for his frequent idealism, his fascination with Kant's categories and his annoying tendency to occasionally make consciousness and human freedom into an a priori, transcendental, absolute faculty. ${ }^{33}$ If Proudhon were really to have succumbed to his idealistic inclinations, however, it would certainly have been at the time of his reading of Spinoza, of the rationalist and logical Spinoza that was then in the process of being invented within the French tradition. Yet it is not so. Proudhon poses a completely different question to Spinoza. He is not satisfied with the abstract freedom that Saisset's translation presents to him, this degree zero of freedom that Proudhon wryly calls "a dry communion, the hypothesis of freedom while waiting for freedom." "34 At the same time, however, he shows how he refuses to be satisfied with the metaphysical void which the theory of free will 
typically implies. ${ }^{35}$ His problem is no longer that of free will, conceived in the form of an abstract, transcendental faculty, a priori and in general, but on the contrary, in the form of the force, or rather of the forces, able to produce man as a conscious and free being. Indeed, in Proudhon's eyes, what Spinoza's system inexorably presupposes, like his own system, is not the absolute, abstract, metaphysical freedom that Bakunin and Malatesta denounce; it is forces and powers, these "free forces" concerning which he asks Spinoza how he can ignore their existence in conceiving human liberation. ${ }^{36}$

How are we to conceive of these primary, foundational powers? How can they themselves give life to a freedom radical enough to deserve the name of free will? One knows (or should know) Proudhon's response, which we can summarize as follows:

(1) Power and freedom are indissociable. Any power is a freedom; any freedom is a power. And it is under this double aspect, indissociable, that the one and the other are, together, the "prerequisite and producer" of any exercise of reason. ${ }^{37}$

(2) Therefore, this power and this freedom arise neither from an a priori transcendental faculty, nor from a primary and foundational human nature. Like reason and like all the properties that man can develop, they are themselves a "resultant;" 38 the resultant of a compound of other powers, ${ }^{39}$ themselves resulting from others compositions, other forces, etc. Proudhon summarizes this when he says that "man is a group." 40

(3) From which comes a Proudhonian first principle. In man, as in all things, that which seems to be in the principle, at the beginning, only comes afterwards, is only an effect of composition-freedom just as much as the soul, the faculties just as much as the ensemble of elements or essences apparently at the origin of the human compound, the unity of creation just as much as the unity of the ego. ${ }^{41}$

(4) Resulting from a sequence and a tangle of other resultants, human power and freedom are not therefore a single, determinate effect, reducible to the sum of the forces and elements which joined to produce them. They never enter a deterministic schema of causes and effects. They are at the same time more and other, distinct from the forces which render them possible. ${ }^{42}$ They are radically new.

(5) Whence comes a second assertion of Proudhon's. Human power [la puissance bumaine] is both a resultant and something free, at 


\section{DANIEL COLSON}

once a radically new, autonomous reality, carrying its own force, and at the same time the expression of the forces and powers which, in composing it, make it possible. ${ }^{43}$ For Proudhon, one cannot dispense with this double assertion, intentionally paradoxical [antinomique]: the radical autonomy of this resultant as its own reality; the radical dependence of this resultant with regard to the forces that make it possible. ${ }^{44}$

(6) One can thus understand the apparent ambiguity of Proudhon's formulas when, in defining human freedom, he speaks at the same time of free forces [forces libres] and free will [libre arbitre]. As a power that is new with respect to the powers that make it possible, human freedom completely justifies the recognition in oneself of the characteristics generally attributed to the concept of free will. Indeed, contrary to what Bakunin thinks and to what some of Proudhon's formulations suggest, the concept of free will and the "inner sense [sentiment intime]" that he affirms are not at all idealist. ${ }^{45}$ Their idealism is only the effect of their ignorance, the ignorance of what makes them possible, of the forces and the play of the composition of forces without which they would be nothing and of which they are, nevertheless, the autonomous expression. ${ }^{46}$

(7) It is in this sense, essential to all of Proudhon's analyses, that human freedom or free will can also transform itself into despotic illusion, into an absolute which is false and authoritarian, believing itself to be the origin of what makes it possible, transforming the deterministic error of the effect into a quite as deterministic error of the cause. The power of human freedom is neither an effect nor a cause but the inevitably autonomous resultant, like any resultant, of a compound of forces without which it is nothing. This, for Proudhon, is what one must understand. ${ }^{47}$

(8) Finally, Proudhon's response reinscribes these balances and contradictions that give his thought its force and its life at the level of life as a whole. As a higher power, human freedom can rightfully and absolutely claim to free itself from all external and internal necessity, by virtue of the complexity and richness of the composition that produces it. ${ }^{48}$ It never ceases to be an integral part of the world that produces it and from which it seems to be so sharply separated. ${ }^{49}$ This for four major reasons.

A. The human compound is no different in any respect from any other compound, from all that composes nature, except in degree of power: 
The living man is a group, like the plant and the crystal, but to a higher degree than these; all the more vital, sensitive, and intelligent since its organs, secondary groups, form a more perfect accord with one another, and form a vaster combination..$^{50}$

B. The freedom specific to the human compound is itself nothing more than a higher degree of a freedom present in any compound, however rudimentary it might be, insofar as freedom is coextensive with the power of the beings:

Spontaneity, to a lower degree in the unorganized beings, to a higher degree in the plants and animals, reached, under the name of freedom, its fullness [plénitude] in man, who alone tends to free himself from any fatalism, objective as well as subjective, and who in fact does free himself." ${ }^{51}$

C. As the resultant of a tangle of powers and spontaneities, human freedom is not an end state. It is a freedom in becoming, the intermediate degree of a power and a higher freedom to be constructed, beginning with all of the powers constitutive of the world and the play of composition that they permit:

In any organized or simply collective being, the resulting force is the being's freedom, so that the more this being, crystal, plant or animal, approaches the human type, the greater will be its freedom, the greater the scope of its free will [libre arbitre]. In man himself, free will reveals itself all the more energetically as the elements which collectively engender it are themselves developed in power: philosophy, science, industry, economy, right. ${ }^{52}$

D. Inscribed within all of the powers constitutive of that which exists, both a posteriori [en aval] and a priori [en amont], human freedom is at once a part and the whole, at once "what there is of the great in nature" and, as Proudhon writes, "the summary of nature, all of nature":.53

Man - multiple, complex, collective, evolutionary-is an integral part of the world, which he attempts to absorb, thereby constituting free will..$^{54}$ 


\section{DANIEL COLSON}

It is in this sense that human freedom, as conceived by Proudhon, can break with the despotic and idealistic illusions of Cartesian freedom and affirm itself as revolutionary. ${ }^{55} \mathrm{It}$ is in this sense that Proudhon announces the anarchist conceptions to come, in particular those of Elisée Reclus, when Reclus affirms "the intimate link that attaches the succession of human acts to the action of telluric forces," when he explains how "man is nature becoming aware of itself," but also when he affirms on the same page, more closely approximating the thought of Proudhon, how "it is from man that the creative will is born that constructs and reconstructs the world." 56

Thus one knows the problem arising from Proudhon and his way of answering it. Even a slightly experienced reader of Spinoza will not fail to be struck intuitively, in a vague but definite fashion, by the proximity (the intimacy, Bakunin would say) that links these two authors. Which contemporary readings of Spinoza, free from the old idealistic and rationalist interpretations, make it possible to confirm or deny this intuition?

\section{The Marxist Interpretation}

Within the current Spinoza revival, the Marxist reading occupies a significant place, closest to the social and revolutionary concerns of Proudhon and with those of libertarian thought more generally, but also farthest from them, as we shall try to demonstrate. The most visible difference, and undoubtedly the most determining, relates to the link which this marxist reading claims to establish between Spinoza's political texts and the whole of his philosophy. Because, from the perspective of this tendency, it is "thoroughly political," Spinoza's thought may not be divided into purely philosophical texts and partly circumstantial political texts. ${ }^{57}$ On the contrary, as A. Matheron endeavours to show, only the political doctrine of Spinoza, because it is homologous with the structure of the Ethics, makes it possible to think interhuman relations and especially to build the concept of individuality so essential to the comprehension of Spinoza's thought and to the interest which we can bring to him. ${ }^{58}$ Even better, as A. Negri demonstrates (and as one could have said of Marx in other times), it is in his last political work, left unfinished, aptly titled the Treatise on Political Authority (TP), that Spinoza would finally become himself, that, at the end of a long process of maturation, promises and crises, his thought finds its completion, the ultimate foundation able to give meaning to all of the earlier writings. 
Undoubtedly such a political reading of Spinoza, for which "Spinoza's innovation" is said to "the imagination of communism...come true," for which Spinozism "is a philosophy of communism," has all the reasons to confirm the objections of Proudhon. ${ }^{59}$ And yet, by virtue of its ingenuity in sometimes coming very close to libertarian positions while at the same time moving further away from them, this interpretation can also seem to largely satisfy the requirements of an anarchist reading [lecture anarchiste] in three ways.

First of all, with regard to the question of God and of origin, the basis of the principal objections made by Proudhon and Bakunin: against an interpretation that has largely predominated up to now, Negri's thesis claims precisely to show how Spinoza comes, through his work, to free himself from God as absolute origin. For Negri, "the Ethics [begins] in medias res....Its abstractly foundational rhythm, then, is only apparent. The Ethics is not in any way a philosophy of commencement, a philosophy of beginning." ${ }^{6} 0$

A second reason to be satisfied by the Marxist and political interpretation of Spinoza: the question of force [force] and power [puissance]. How, asked Proudhon, can Spinoza conceive the liberation of man without necessarily presupposing the existence of free forces capable of such a liberation? There, too, certain of Negri's formulations would seem to satisfy Proudhon's objection completely. Human subjectivity, collective and individual, conceived by Proudhon in the form of a compound of forces and powers, corresponds, in nearly identical terms, to the way in which Negri's Spinoza is supposed to think the subject and subjectivity: in the form of a "subjective continuity" of the "power of being [puissance de l'etre]," 11 "a powerful being, which knows no hierarchies, which knows only its own constitutive force." ${ }^{2}$

The third and last point of agreement, which follows from the previous: the refusal of mediation. Against a traditional interpretation which tends, in one way or another, to place Spinoza on the side of Hobbes or Rousseau, on the side of the social contract and a juridical vision of democracy, Negri attempts to clearly establish "Spinoza's juridical positivism." "63 As Matheron forcefully writes in his foreword, for Negri's Spinoza, "right is power [le droit, c'est la puissance], and nothing else." ${ }^{64}$ The State (heir to the old precapitalist absolutism), bourgeois civil society as a democratic counterweight, relations of production as the organization and form of coercion, et cetera: every "mediation of the productive forces" is radically rejected by Negri's 


\section{DANIEL COLSON}

Spinoza. ${ }^{65}$ "In Spinoza there is... [no] sign of mediation. Spinoza's is a philosophy of pure affirmation... a totalizing philosophy of spontaneity." ${ }^{66}$ How could anarchism, which made direct action and the refusal of any intermediary, of any representative, one of the essential axes of its thought and its practice, fail to endorse an interpretation for which "the denial of the concept of mediation itself resides at the foundation of Spinozian thought"? ${ }^{67}$

There are thus three good reasons for libertarian thought to endorse the Marxist interpretation of Spinoza; but three reasons almost too beautiful, which accentuate to the point of caricature the features that one usually associates with anarchism: its absolute immanentism and the immediacy of its position and points of reference; its refusal of any mediation, any waiting, any regimentation, any delegation and any representation; the exacerbated and subjective voluntarism of a utopian vision claiming to submit itself to reality, immediately and directly. Three reasons which, in their very radicality, also bring to mind the disrepute of a movement associated, for more than a centuryfrom the Marx of The Civil War in France to Pol Pot's Democratic Kampuchea, passing through Lenin's State and Revolution and the Maoist Cultural Revolution - along with other disguisings of its position, other simplifications, other tinkerings with a libertarian practice and vision all the more complex and subtle for the fact that it can attest more visible manifestations and more current detractors.

Without entering into an exhaustive discussion of Negri's analyses, it suffices to observe how, in their approach and their conclusions, they tend to verify Proudhon's worst fears. In media res, begin in the middle of things, A. Negri tells us; and, more precisely, begin from multiplicity, the "particular beings" which populate the "world of modes." ${ }^{\prime \prime}$ But against the radicality of this first and this second assertion, which are not the subject of any consequent development, is opposed at once the negative abstraction, every bit as radical but now developed at length, of the third: the refusal of any mediation. A violent and absolute refusal which quickly leads Negri, thus without transition, to affirm the "unity" and "univocity of being," of which all of these "things" are no more than the "emanation," to affirm the "absoluteness of the potentiality of being," as well as the "source" of "the thousand and one singular actions of each being," to affirm the "density," the "totality" and the "centrality" of a single being 
of which the modes are no more than "forms," "variations," and "figures," to affirm the "transparency" and the "unifying force" of being, in short, to unceasingly affirm and reaffirm "being" or the "divine" as the "expression of infinite power." 69

Between the modes and the substance there is nothing. Such is Negri's thesis about Spinoza. Or rather-and it is here that Negri's assertions, so ostensibly libertarian, move infinitely far away from the anarchist project - in this "nothing," there is the politics that justifies and necessitates political power, the absolute power of politics, the political absolute denounced by Proudhon, this almost-nothing that does everything and that makes all the difference to the libertarian project. In a deafening theoretical echo of the Maoism of the Cultural Revolution, Negri refuses any mediation of being, but only the better to entrust to politics the frightening prerogative, not only of "mediat[ing]" its power and its truth, but also of "constituting" it as "power" and as "truth," of giving it its "existence," through its most perfect "constitution," this "revolution" without "becoming" which is the "omnino absolutum imperium" of "democracy."

In Negri's Spinoza, "being" and "political subjectivity" are only the two faces of one inescapable sequence of thought, a thought based on the double absolute of religion and politics, the necessary and the arbitrary, of "absolute necessity" as the absolute justification of an absolute arbitrariness; ${ }^{71}$ an absolute in the mirror in which communist being realizes itself, in the flawless ballet of the politics that embodies it directly, in which things and men are actually condemned to take part in most appalling of despotisms, with the harmony or (according to the moments) with the mass punishment of political orchestration of bodies and souls which tolerates no variation, no gaps, no hesitation, no fumbling, no disagreement, no crisis, no inevitably negative criticism, no inevitably dubious history, no inevitably groping experiment, in short, no becoming.

As Negri writes:

The contemporaneity of Spinoza consists first of all in this: being does not want to be subjected to a becoming that does not possess truth. ${ }^{72}$ Truth is said of being, truth is revolutionary, being is already revolution....Becoming manifests its falsity when faced with the truth of our revolutionary being. It is not by chance that, today, becoming seeks to destroy being and suppress truth. Becoming seeks to annihilate the revolution... a crisis is 


\section{DANIEL COLSON}

always a negative violation of being, set against its power of transformation. ${ }^{73}$

And it is spontaneously and without surprise that Negri's revolutionary enthusiasm joins again, naturally, with the religious gestures of submission to the absolute that Proudhon and Bakunin had been so quick to find in Spinoza:

The world is the absolute. We are happily overwhelmed by this plenitude, we cannot help but associate ourselves with this superabundant circularity of sense and existence. 'You spare all things because all things are yours, Lord, lover of life/you whose imperishable spirit is in all.'....Such is the content of being and revolution. ${ }^{74}$

Within the framework of this study, it is not possible or even useful to analyze in detail the dead end and the impotence of a interpretation which, through the concepts of the multitude, the imagination, and the individual, struggles vainly to give any material content to the politics of the "constitution" of "being." Faithful to the despotic tradition to which he adheres, Negri himself is happy to mask the terrifying void of his political conception behind a interminable pedagogical evaluation of the progress and regress of Spinoza along the way to the truth: through "discrimination[s]" and "caesura[s]," "limits" and "interruption[s]," "destruction[s]" and "reconstruction[s]," "decisive choice[s]" and "critical threshold[s]"; but also "cris[es]" and "intermediate moment[s]," "block[ages]" and "leap[s] forward"; or, "approximations" and "weak" moments, "confusions and dissymmetries," "step[s] backward" and "slippage[s]," "uncertaint[ies]," and "intrasystemic disequilibri[a]"; and then again, "retreats" and "banalit[ies]," "ambiguit[ies]" and "confusion[s]," "reversal[s]" and "residual elements," etc., ${ }^{75}$ in preparation for the final silence of the incompletion of the TP, where, with a show of false regret, the "imagination" of the revolutionary leaders (and other Pol Pots of being) can finally deploy itself without obstruction.

Proudhon reproached Spinoza for three things: (1) taking God, the absolute, as his starting point; (2) linking his political conceptions to this metaphysics of the absolute, thereby leading to the most "appalling of despotisms"; (3) being unable to account for the freedom which, paradoxically, his system necessarily presupposes. Under the pomp of its revolutionary proclamations, the Marxist interpretation can only confirm - with a strange power, one might say — the first two 


\section{ANARCHIST READINGS OF SPINOZA}

objections. But in so doing, the Marxist interpretation, like Proudhon's, can only run up against the third, a rather wrongheaded objection, which is astonished by Spinoza's very text, by what it "incredibly" continues to say in spite of what it seems to say, in spite of what one makes it say; a perverse and stifling [entêtée et entêtante] objection that even Negri cannot prevent himself from opposing to his own conclusions:

If, as Spinoza would like, democracy is an ordered system constitutive of absoluteness [this is Negri's thesis], how can it simultaneously be a regime of freedom? How can freedom become a political regime without repudiating its own naturalness? ${ }^{36}$

Or again, in terms almost identical to those of Proudhon's critique:

How can a philosophy of freedom be taken up again in an absolute form of government; or, vice-versa, how can an absolute form of power be compatible with a philosophy of freedom...how can absoluteness and freedom be made compatible? ${ }^{\text {?7 }}$

And, a little further on:

"Do we not perhaps find ourselves in the presence of a totalitarian utopia...[in which] every distinction and determination vanishes? ${ }^{78}$

It would be difficult to state more forcefully the need for another interpretation of Spinoza.

\section{Another Reading of Spinoza}

In a recent text, A. Matheron, one of those who, well before Negri, contributed to the further development of a political and marxist reading of Spinoza, provides, after years of research and interrogation, an ultimate explanation of the incompletion of the TP, the non-writing of the final section on democracy which, according to Negri, is supposed, even by its absence, to give the direction of the whole of Spinoza's philosophical direction. ${ }^{79}$ In a slightly disillusioned way, A. Matheron wonders whether Spinoza, in his concern for intervening effectively in the political struggles of his time, did not hesitate to reveal a terrifying truth: not, as Negri thinks, the joyous secret of the liberation and revolution to come, but, on the contrary, and in an indisputably 


\section{DANIEL COLSON}

anarchist sense this time, the overpowering certainty that "at the very root" of political society and the State there is "something irremediably bad." ${ }^{80}$ For the belatedly anarchist Spinoza of Matheron, and against the communist Spinoza of Negri, nothing is to be expected from politics, even of the democratic variety, since "the elementary form of democracy, according to Spinoza, is lynching," and the "power of the multitude" only seeks to ensure the safety of "conformists" and to repress "deviants." ${ }^{81}$ Consequently, only a "community of the wise" could lay claim to a collective life liberated from fear and obedience, but, as A. Matheron remarks, "we would have a democracy without an imperium then, and it would not really be a State any more." ${ }^{82}$ Thus, anarchy.

Beyond the easy irony that the logical spirit of theoretical Marxism never fails to evoke, A. Matheron's final conclusion, which, like the straw that broke the camel's back, topples thirty heavy years of the political interpretation of Spinoza, at least presents the novelty of reminding us that another reading of this philosopher is possible; a reading that, to begin with, would attempt to rigorously distinguish what Marxist interpretation attempts to confuse: to separate the political writings (with their rather particular reasons for being) from the Ethics and the other philosophical works (with their own radically different ends), ${ }^{83}$ separating the "absolute form of power," which one can indeed deduce from the former, from the "philosophy of freedom" proper to the latter.

As G. Deleuze recalls, because it is subject "to an extrinsic order, determined by passive feelings of hope and fear," and founded on obedience, commandment and interdiction, sin and guilt, merit and demerit, good and evil, political society, no matter how good it may be, can in no case have the same goal as the philosopher. ${ }^{84}$

It is certain that the philosopher finds the most favorable conditions in the democratic state and in liberal circles. But he never confuses his purposes with those of a state, or with the aims of a milieu, since he solicits forces in thought that elude obedience as well as blame, and fashions the image of a life beyond good and evil, a rigorous innocence without merit or culpability. The philosopher can reside in various states, he can frequent various milieus, but he does so in the manner of a hermit, a shadow, a traveler or boarding house lodger. ${ }^{85}$ 
It is true, if one excludes the explicit reference to Nietzsche, that Deleuze's distinction can itself seem to fall under a completely traditional interpretation of Spinoza, with a program for the multitude, the crowd, and the vulgar on one side, irremediably subject to passion and to imagination, whom a "civilizing" State must guide and manipulate from the outside, and on the other side, the few, the elite of philosophers, hermits and unattached individuals, only able to accede to reason by themselves, inwardly, by the force of thought and even by their solitude. ${ }^{86}$

A heretic for Yovel, a deviant for Matheron, a grand vivant for Deleuze, anxious to invent a new man to break with the man of the masses, the plebs, the crowd, and the herd, undoubtedly the Spinozist philosopher can claim, from Max Stirner to Michel Onfray, from Nietzsche and Jean-Marie Guyau to Albert Libertad and Georges Palente, to echo an entire dimension of anarchism: its individualistic dimension. But how, from the libertarian point of view, could this absolute opposition of the individual to the social open up to an interpretation of Spinoza which, while relativizing or leaving behind the political writings, would attempt to find in the individuality of the philosopher the place and principle of a collective emancipation of humanity? By what paradox of libertarian thought is it that politics per se - the action of the mass, the multitude (thought under the negative sign of communism, despotism and conformism) - is precisely what collective liberation must get away from, making its way instead via the exigencies and possibilities of individual liberation?

One saw how Proudhon endeavoured to think this paradox, in particular through his refusal to oppose the individual and the group, through his conception of the individual as composed of powers and his assertion that the individual is a group. ${ }^{87}$ However, in another way, he is no less on the side of various interpretations of Spinoza, where the multitude and the individual (in the modern sense of the term) are not necessarily where one initially thinks to locate them.

\section{Communism and the multitude of individuals}

A paradox of the political interpretation first of all, centered on the emergence of politics and its "constitution of being": an emergence that is yet to come, since it is identified with the revolution, and a constitution as a "project" that can find its full and true expression only in the vacuum and incompletion of the $T P{ }^{88}$ Projected into the future, it is quite necessary, however, that this constitution have a present and a past (or some antecedent) that justify one's speaking of it in the 


\section{DANIEL COLSON}

present, that can materially found the future existence of the multitude. Negri endeavours to grasp this present and this past, as the genesis of what is being born, as a striving towards the future, through what he calls a genealogy: the "genealogy of collectivity." 89

This genealogy presents two faces. In the first place, it follows Spinoza's path, the trajectory of a difficult and discontinuous search, from the "positive utopia," the "mystical" and "pantheist" utopia of the Short Treatise, to the incompletion of the TP, passing through a sometimes recurring succession of "metaphysical," "physical," "baroque" and "mystical" conceptions. Inevitably retrospective, and although it is central to The Savage Anomaly, this chronological reading of the path or, rather, the paths followed by Spinoza in his search for being, is however not yet, to be strictly accurate, the "genealogy of collectivity" that Negri claims to bring to light. ${ }^{90}$ Pedagogical and interpretive, he aims above all at showing how Spinoza becomes Spinoza. ${ }^{91}$ A rigorous pre-genealogy, or a negative genealogy, ${ }^{92}$ this reading painstakingly follows Spinoza's process of becoming, from one crisis to the next, because it knows the end of the story, and therefore it can patiently accept the mistakes and deviations that any process of becoming entails, with its "impasse[s]" and its "blocking[s]", its "approximations" and its "weaknesses," its "ambiguities" and its "confusions," its "uncertainties" and other "errors," "enigmas" and "hypostases." "93 can in no way be confused with the genealogy of collectivity and the revolution, for which it is satisfied, at best, to prepare the way, as John the Baptist prepared the way for Christ.

In Negri's analysis, the true Spinozist genealogy of collectivity and revolution are to be found elsewhere. He begins where Spinoza's search ends, in 1664 or 1665 to be precise, at the moment of the second Anglo-Dutch war, when, straying into contradictions and the pantheist labyrinth of the end of book II of Ethics, he makes a true epistemological break. ${ }^{94}$ At this point in time, Spinoza finally discovers what he had anticipated since the beginning, what he had sought for such a long time: the importance of politics, and more precisely still, of the "subject" of political action.

Indeed, with the drafting of the TP and its supposed philosophical translation into books III and IV of the Ethics, it is not only politics and its phenomenology, full of fury and superstitions, that irrupt into Spinoza's system. The essential innovation, the "ontological inversion" that, for Negri, finally yields the possibility of a true genealogy of collectivity, is the revelation of the "subject" of this 
political action; ${ }^{95}$ it is the invention of "human individuality" as the primary condition and foundation of the multitude and thus of the constitution of being. ${ }^{96}$ For Negri, with the TP and books III and IV of the Ethics, Spinoza at last (not without relapses) escapes from the pantheist, naturalist, physical and metaphysical fogs of his former attempts. He can finally "pass" from "physics... into physiology and [from] physiology into psychology"; he can finally traverse "the genealogy of consciousness," passing "from conatus to the subject". ${ }^{97}$ Abandoning the vast pantheist horizons and metaphysics of the world and nature, "Potentia, the general figure of Being," finally condenses into cupiditas, this human form of the conatus, and "invests the world of historical passions and relations"; while waiting for the TP to complete this first genealogy and show, even by its incompletion, how, starting from this "constitution of the individual," these "formed individuals," these "individual powers" ("this first level of socialization"), "Sovereignty and Power" are finally "flattened onto the multitudo and onto the processes that proceed from individuals to the constitution of the State." 98

Here is the paradox of the political interpretation of Spinoza: while believing that it opens onto the infinity of the multitude, it locks itself up in the dubious straightjacket of the individual. ${ }^{99}$ The collective infinite changes into the indefinite. ${ }^{100}$ And the definite is limited to the conceptual poverty of a subject reduced to a word-for-word reiteration of the moral treatises of seventeenth century. ${ }^{101}$

\section{Anarchy and multiple individuality}

If the paradox of the political multitude is to be thought starting from the individual, on the quantitative register of the same (communism), one could say that the paradox of the philosopher's "individuality" is to be thought starting from the multiple, on the qualitative register of the different (anarchy).

To properly understand the sense (physical and conceptual) of this double paradox, it is necessary to cross two centuries, to go for a moment to the Ukraine, where anarchy and communism clashed directly. In the book Arshinov wrote in 1921 on the Makhnovist libertarian movement, in the heat of the action, after four years of cruel and complicated struggle on the immense plains of the Ukraine, he concludes thus, solemnly, in counterpoint to the old slogan of the First International: "Proletarians of the world, look into the depths of 


\section{DANIEL COLSON}

your own beings, seek out the truth and realize it yourselves: you will find it nowhere else." 102

By its strangeness, this call rather aptly expresses the direction taken by another reading of Spinoza, a reading that appears strictly philosophical and individual, that seems to want to turn away from politics itself while at the same time it announces a collective project of an altogether different nature. ${ }^{103}$

As the antiquated psychological foundation of a hypothetical collective future, the human individual postulated by the political Spinoza is first of all an end, as one has just seen, a goal long sought for, something promised for the future, but one that, once found, effaces the long wanderings that preceded it. The other interpretation is precisely the reverse of this. In place of a political reading that starts from the vast spaces of Spinoza's thought, only to transform them into simple horizons and to end up in the walled garden of human passions, the philosophical and libertarian interpretation of Spinoza begins with the human individual, with the apparent simplicity and banality of its psychological operation, only to open it up to the vastness of the nature of which it is only a part, to the infinity of that which exists and what it is capable of. ${ }^{104}$ Fortitudo (with its double aspect of Animositas and Generositas), Titillatio, Presentia Animi, Humanitas, etc., the long list of the definitions (more than seventy) that help Spinoza to grasp the nuances of the human experience, may well be borrowed from the most current representations of the seventeenth century, from the most worn moral treatises and from the voluntarily mechanical use of the theory of the passions. ${ }^{105}$ Like the scholastic concepts or the very ordinary Latin that Spinoza employs, they are used for very different ends, opening onto very different realities than what their psychological banality might lead us to believe. It is in this sense (among others) that Spinoza can be brought closer to Nietzsche:

The philosopher appropriates the ascetic virtueshumility, poverty, chastity — and makes them serve ends completely his own, extraordinary ends that are not very ascetic at all, in fact. He makes them the expression of his singularity....Humility, poverty, chastity are his (the philosopher's) way of being a grand vivant, of making a temple of his own body, for a cause that is all too proud, all too rich, all too sensual. ${ }^{106}$ 
"Proletarians of the world, look into the depths of your own beings!" The point of arrival in the Marxist interpretation, the point of departure in the philosophical and libertarian interpretation, the human individual and its passions occupy more than one position contested by the different readings of Spinoza. ${ }^{107}$ To this difference in place correspond other oppositions that bear first of all on the nature of this individuality and the orientation in time of the process of transformation in which it is engaged.

First, the orientation in time. If the political Spinoza proceeds in two definitely distinct times, from the initial pantheism to the individual, then from the individual to the multitude, these two movements work in the same direction, so that the time of things comes to coincide with the time of thought, from the past towards the future, from the beginning to the end, from the naturalist and metaphysical origin of being to its political constitution, "from nature to second nature, from physics to human action," from the infinite foundation of things and of signs (this "dark complexion" of existence of which Negri speaks) to the narrow, closed field of human desires, to the battlefield of politics, where, in a cri du coeur, Negri dreams of one day seeing the "infinite" finally submitted to "organization."108

The direction taken by the philosophical and libertarian Spinoza is of a radically different nature. Foreign to a linear conception of time, in which Macherey has no trouble recognizing, in spite of Negri's denials, the deeply Hegelian vision of Marxism, ${ }^{109}$ he sets a very different time to work, multiple and qualitative, which is due to the duration of things, "to the reality of enduring things" of which B. Rousset speaks, ${ }^{110}$ and to the relations of composition, recombination, and decomposition which increase, decrease, or destroy these existing things' power to act. ${ }^{111}$ If it were necessary, at any cost, in order to be able to compare them, to translate the duration of the libertarian Spinoza onto the temporal register of the political Spinoza, it would be necessary to speak of an a posteriori and an a priori. Whereas the political Spinoza proceeds from a priori to a posteriori, from the foundation of things to individuals, then from individuals to the multitude, one could say that the other Spinoza operates from a posteriori to a priori, from individuals such as they exist at present towards what constitutes them as individuals, from the closed field of political passions towards the obscure and infinite foundation of the realities that they mask, from the immediate given towards the infinity from which it results as a finite composition and thus as a singular expression of an infinite otherness. 


\section{DANIEL COLSON}

The philosophical and libertarian Spinoza claims the revolution no less than does his political brother-enemy, but for him, the revolution to come is not aposteriori, in the emptiness and arbitrariness of a political constitution the materiality of which would be reduced to the passions of human nature. It is a priori, in the infinity of "possibilities," the present forms of individuation of which are only an actual expression, a point of departure. ${ }^{112} \mathrm{As} \mathrm{B}$. Rousset attempts to show, contrary to the emptiness and material poverty of the political imagination, these possibilities or potentials, prior to the human individual, the foundation of that of which it is capable, are neither the unreal and erroneous products of the imagination nor mere virtualities (in the scholastic sense of the term). ${ }^{113}$ As "practical theses," "real possibilities," they are "implied" in the "being inhexhaustible" in which the human experience unfolds. "They exist "by implication" in one duration which is identified with "movement" and "life," or, in the vocabulary of Deleuze, with a "plane of immanence or consistency, which is always variable and is constantly being altered, composed and recomposed, by individuals and collectivities." 115

If the Spinozist possibility can thus be thought prior to the current moment, and if the Spinozist future can be thought in the past, this is absurd or paradoxical only on the register of linear or dialectical time (so foreign to Spinoza). In the libertarian interpretation of Spinozist duration, past and future, the a priori and the a posteriori, merge in an untimely present in which all is given, in which duration depends on the multiplicity of things, virtual and formal, in which, contrary to the scholastic meaning of these terms, the virtual is no less real than the formal, the power no less real than the act. ${ }^{116} \mathrm{It}$ is in this sense that the Spinozist "foundation" and the libertarian "depths" of which Arshinov and Proudhon speak, are very precisely a surface, an already-there [déja-la], a present, patient and impatient, in which everything is always there as possible, a present in which "all is possible." It is also in this sense, on the side of or parallel to libertarian thought itself, that Spinoza can be related to the very Leibnizian G. Tarde, for whom it is appropriate to refuse to consider being or the individual as "foundational [souches premières]", as some "absolutely primary given," but only as some presently existing "emergents" from an infinity of other possible emergents, other "possibilities," struggling with one another to exist. ${ }^{117}$ It is in this sense, finally, closest to us, that Spinoza's conceptions can be linked to an entire dimension of the thought of G. Simondon, for whom "the individuation of beings does not completely 
exhaust the potentials of the individuation," for whom "the individual....exists as superior to itself because it contains within itself a more complete reality that the process of individuation did not exhaust, that remains new and potential, animated by potentials"; a reality that G. Simondon calls "nature," i.e. the "reality of the possible, under the species of that apeirôn from which Anaximander draws each individual form." 118

We do not even know what a body is capable of. Balibar is right to emphasize, contra Negri, the respect in which Spinoza's concept of human individuality is in no way comparable to a subject, a consciousness or a person. He is right to explain why the object of the Ethics is not the individual (in the modern sense of the term), but "the form of individuality"; he is right to affirm, like Proudhon, that "all human individuality is caught up...in the in-between of the inferior forms of individuality that are composed in it - but whcih are not for all that dissolved in it — and of the superior forms of individuality into which it can enter." 119

But Balibar was wrong to reduce this immense play of the composition of possible individuals to the narrow passional and affective field of interhuman relations (the theory of the passions), to entrust to it, not without a certain inexactness, the care of constituting human subjectivity in a transversal fashion, thinking thereby to assure, better than Negri, the transition from the multitude to politics. ${ }^{120}$

Because they are grasped not in the in-between [entre-deux] but in the in-between-thousands [entre-mille] of all the other relations and individuals that comprise human nature, the human passions are no more "a kingdom within a kingdom" than the individualities that they affect. ${ }^{121}$ Because they are taken on between the inferior forms of individualities which are composed in them and the superior forms of individuality into which they can enter, the various human individuals are themselves only a modality of the infinite forms of individuals which, to differing degrees and through successive agreements, compose

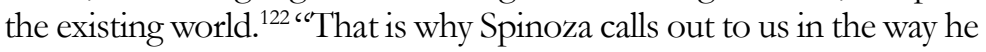
does: you do not know beforehand what a body or a soul can do, in a given encounter, a given arrangement, a given combination." 123

In the foreword which he gave to the French translation of Negri's book, Deleuze thus summarizes his own manner of reading 


\section{DANIEL COLSON}

and of understanding Spinoza and, in a certain way, taking into account the circumstances, his own way of conceiving Spinoza's politics:

Bodies (and souls) are forces. As such they are not only defined by their chance encounters and collisions (state of crisis). They are defined by relationships between an infinite number of parts that compose each body and that already characterize it as a 'multitude.' There are therefore processes of composition and decomposition of bodies, depending on whether their characteristic relationships suit them or not. Two or several bodies will form a whole, in other words, another body, if they compose their respective relationships in concrete circumstances. And it is the highest exercise of the imagination, the point where it inspires understanding, to have bodies (and souls) meet according to composable relationships. ${ }^{124}$

It is undoubtedly in this text, collected and abstracted and yet so Proudhonian in its form and content, that the meeting between a philosophical and libertarian reading of Spinoza and the anarchist thought itself appear most clearly; in three great ways:

(1) First of all, in connection with the multitude. No doubt the quotation marks that Deleuze employs serve to mark a certain distance, to mean that it is about a notion specific to the author whom he prefaces and that this word is not among Spinoza's principal concepts. ${ }^{125}$ But they also serve to show how, by employing the word multitude and by reintroducing it to the heart of Spinoza's philosophy, Deleuze transforms its initial political significance completely. If, for Proudhon, the individual is a group, a compound of forces or powers which differs from all the other compositions (minerals, plants and animals) only in degree, the Spinoza of Deleuze does not say otherwise. ${ }^{126}$ With Proudhon and against Negri, the multitude ceases to be the hypothetical and imperceptible horizon of a revolution to come; it is already there, at hand, in us and around us. The multitude is no longer the final and unifying synthesis of all the human individualities led by only one soul, on the side of the infinitely large (the "constitution of being"); it is geared down in an infinity of multitudes, inside an infinity of body and hearts, on the side of an infinity of infinitely small things. ${ }^{127}$ Better still, because it is interior to each body and each soul, therefore with all the bodies and all the souls, the multitude ceases 
being attached to only human realities, human individuality and the narrowness of its passions. Interior to any thing, it embraces the totality of bodies and souls, the totality of individualities, whether they are human or non-human.

(2) Secondly, force. "Bodies (and souls) are forces," Deleuze tells us, and it is "as such" (a) that by relationship between an infinity of parts they are defined as multitude; (b) that they are grasped (soul and body) in some "processes of composition and decomposition...depending on whether their characteristic relationships suit them or not." In short, this force that Proudhon demands from Spinoza, which he himself identifies with the resultant of a compound, and which, for Negri, is transformed into an abstract and general entity (the "power of being"), Deleuze reinscribes at the center of Spinoza's analyses, in each body (and in each soul) and in the most material sense possible (physical, chemical, biological).

Thanks to force and the multitude, the Spinoza of Deleuze reunites what the political interpretation of Spinoza had endeavoured to separate, nature and second nature (Negri), the human and the nonhuman (Matheron): ${ }^{128}$ "One Nature for all bodies, one Nature for all individuals, a Nature that is itself an individual varying in an infinite number of ways." 129

Again, as Deleuze says, the "plane of Nature... does not make any distinction at all between things that might be called natural and things that might be called artificial." ${ }^{\prime 130}$ Plane of immanence and unity of composition, ${ }^{131}$ or, in the vocabulary of Bakunin this time, the "universal...combination of the infinity of particular actions and reactions which all things having real existence incessantly exercise upon one another," 132 the processes of composition and decomposition of bodies and souls, all correspond to a physico-chemical model, whether they are human or not. ${ }^{133}$ Even the common notions which, starting from what is most universal, command the rational and geometrical architecture and development of the Ethics, are also, in their construction, not only a "mathematics of the real or the concrete," but specifically "physico-chemical or biological Ideas rather than geometric ones."134 And ethics itself, this specificity of the human power, is also, in its origins as well as in its applications, a "test" of a physico-chemical type. ${ }^{135}$

(3) Finally, freedom. Reduced to that which exists, to the $a$ priori of possibilities, the various forms of the individualities which can cover human existence can well embrace the infinite totality of material 


\section{DANIEL COLSON}

determinations, to be material throughout. Contrary to appearances and to the a priori idealists of dualistic thought, they are not in any way reduced to natural forces, to the non-human (even to the inhuman). Quite to the contrary; it is thanks to this persistent return to that which founds and constitutes his existence, to the material infinity of possibilities, that man can claim to reach a world of freedom, in a human world, a world to himself, a world where, ceasing to be separated from his force, he finally becomes master of his power to act. As Deleuze writes, 'What defines freedom is an 'interior' and a 'self' determined by necessity....Man, most powerful of the finite modes, is free when he comes into possession of his power of acting." ${ }^{136}$ Power, freedom, power to act, interior, "self": even if the theoretical references are different, we thus find Proudhon's vocabulary and prospects: "If man thinks for himself, if he produces his ideas as his right, he is free."137

Such is the goal for Proudhon as well as for the Spinoza of Deleuze, the Spinoza of knowledge through common notions. ${ }^{138}$ And the question that this common goal implies is also the same: how to think for oneself? How to produce one's ideas and one's right? ${ }^{139}$ For the Spinoza of Deleuze, signs and experience are required: signs or ideas as "dark precursors" of the common notions; ${ }^{140}$ experience or experimentation as the precondition for any thought, for any reappropriation of power, and thus for any freedom. ${ }^{141}$ For Proudhon, signs and action are needed: signs or ideas which are certainly a priori untrue and a source of slavery, but the origins of which can be found and which, brought back to that which produces them (acts, facts, instinctive thought), can make it possible for man to free himself and to think for himself:; ${ }^{142}$ action as the condition of signs and thought, as foundation of power and freedom. ${ }^{143}$ In both cases the process is the same: to start with signs as an immediate condition and to arrive at a thought that is free and for itself [par soi-même] (or, for Deleuze, in itself [en soi]), but to do so in order to get back at once to the source of all thought and all freedom: experimentation for Spinoza, action for Proudhon and, after him, the principal currents of the libertarian movement.

It is true that Proudhon (in De la Justice at least) tends to link this action exclusively to labor, "one and identical in its plane [and] infinite in its applications, like creation itself," ${ }^{144}$ whereas for the Spinoza of Deleuze the "plane" of human experience, the "plane of immanence or consistency, which is always variable," is "Nature" as a whole. However, in these two approaches, as different as they can be otherwise, 
it is a matter of: 1) locating this experience or this human action on an infinite plane of composition, through relations that Spinoza calls common notions (thoughts on a physico-chemical and biological model) and that Proudhon calls elements of knowledge or elements of labor (thought on a physico-mathematical model instead). ${ }^{145} 2$ ) bringing back these experiments or these actions of composition to the forms of interiority, increasingly broader and more complex, which constitute the human compounds; for the Spinoza of Deleuze, by selection, selection of the "bodies that agree with our own and give us joy, that is, that increase our power", ${ }^{146}$ for Proudhon, by the interiorization of the relations of labor, an interiorization that dates from time immemorial (at the origin of humanity as well as of each individual) but which is continually repeated, spreading to cover the infinite plane of composition of human industry. ${ }^{147}$

A body and a soul among other bodies and souls, but "the most powerful of the finite modes," and "free when it comes into possession of its power of acting," man thus has the capacity to experiment, to learn to know what is good and bad for its power to act, for its freedom. ${ }^{148}$ And it is through this experimentation with the relations that agree with it, at the interior and on the exterior of what constitutes it, with refusals and approvals, with yes and no, with associations that are always revocable, that it can extend these relations to increasingly vast forms of association, disposing of an ever more "intense" power, no longer concerned with instrumentalizations or appropriations, but with sociabilities and communities. ${ }^{149}$

In contrast to the political city of which Negri dreams, the philosophical and libertarian emancipation that one can read in Spinoza then ceases to be founded on fear or anguish, reward and punishment. As Proudhon and Bakunin wished, it ceases to rely on the State, trusting the State to "[take] the place of reason for those who have none," i.e., for the majority, for the slaves. ${ }^{150}$ Renouncing any external coercion, even when this calls itself enlightened, emancipation can emerge from "relations that directly and naturally combine," from "powers or rights that are naturally additive." ${ }^{151}$ It can claim to emerge directly from individuals and collectivities (which are themselves collectivities of individuals), from their capacity to transform, compose, and recompose ad infinitum the "plane of immanence or consistency, which is always variable," of that which exists. ${ }^{152}$ 


\section{DANIEL COLSON}

Université de Saint-Étienne, Lyon, France Translated by Jesse Cohn \& Nathan Jun

\section{Notes}

${ }^{1}$ Habermas being undoubtedly the most spectacular example of this return to Kant.

${ }^{2}$ But also French materialists, in particular Diderot.

3 "If man obeys laws of nature, he is therefore by no means a slave, since he is obeying only laws which are inherent in his own nature, under the conditions of which he exists, which make up his entire being. When he obeys them, he obeys himself." Mikhail Bakunin, Oeuvres completes (Paris : Éditions Champ libre, 1975), VIII, p. 201.

${ }^{4}$ Bakunin, Oeuvres complètes, VIII, p. 192

${ }^{5}$ Bakunin, Oeuvres complètes, I, p. 137.

${ }^{6}$ Bakunin, Oeuvres complètes, VIII, p. 91

${ }^{7}$ On the dual causality of which Spinoza's thought provides an example, "the first [horizontal] being constituted by the indefinite series, and the second [vertical] by God," see Gilles Deleuze, Spinoza philosophie pratique (Paris: Éditions de Minuit, 1981), pp. 78-79. See also Yirmiyahu Yovel, Spinoza et autres hérétiques (Paris: Seuil, 1991), pp. 208 ff.

${ }^{8}$ Deleuze, Spinoza philosophie pratique, p. 78.

9 "I am a fanatical lover of liberty....I mean the only liberty worthy of the name...the liberty which knows no other restriction but those set by the laws of our own nature. Consequently there are, properly speaking, no restrictions, since these laws... are subjective, inherent in ourselves; they constitute the very basis of our being." Bakunin, Oeuvres complètes, VIII, pp. 291-292.

${ }^{10}$ On this point, see the criticism of Feuerbach: "Not Deus sive Natura but aut Deus aut Natura is the watchword of Truth," in Geschichte der neuern Philosophie von Bacon von Verulam bis Benedict Spinoza, as cited in Georgi Plekhanov, Oeuvres philosophiques (Paris: Editions de Moscou, 1961), Vol. 2, p. 374

${ }^{11}$ Pierre-Joseph Proudhon, De la Justice (Paris: Rivière, 1927), II, p. 84.

12 Proudhon, De la Justice, III, p. 220.

${ }^{13}$ Proudhon, De la Justice, II, pp. 182 and 180.

${ }^{14}$ Proudhon, De la Justice, III, p. 22.

${ }^{15}$ Proudhon, De la Justice, III, p. 22. Proudhon here repeats, almost word for word, Spinoza's Tractatus Theologico-Politicus, chapter 10.

${ }^{16}$ Proudhon, De la Justice, II, pp. 183-184. Proudhon is here referring to Tractatus Theologico-Politicus, chapter 16. Proudhon was 


\section{ANARCHIST READINGS OF SPINOZA}

unaware of Spinoza's Tractatus Politicus, which Saisset had not yet translated.

${ }^{17}$ Proudhon, De la Justice, III, p. 22; and III, p. 173.

${ }^{18}$ Proudhon, De la Justice, III, pp. 185 and 175.

${ }^{19}$ Proudhon, De la Justice, III, p. 177.

${ }^{20}$ Proudhon, De la Justice, III, p. 177-178.

${ }^{21}$ Proudhon, De la Justice, III, p. 178.

${ }^{22}$ Proudhon, De la Justice, III, p. 376.

${ }^{23}$ Proudhon, De la Justice, III, p. 371.

${ }^{24}$ Proudhon, De la Justice, III, pp. 371 and 375.

${ }^{25}$ Proudhon, De la Justice, III, p. 373.

${ }^{26}$ Proudhon, De la Justice, III, p. 376.

${ }^{27}$ Proudhon, De la Justice, III, p. 372.

${ }^{28}$ Translation of 1840 . On its use by Proudhon, see

Proudhon, De la Justice, III, p. 374.

${ }^{29}$ On this idealist and rationalist interpretation of Spinoza, see Robert Misrahi, Ethique (Paris: PUF, 1990), pp. 9-10; and PierreFrancois Moreau, Spinoza et l'expérience (Paris: PUF, 1994), pp. 227 ff.

${ }^{30}$ Proudhon, De la Justice, III, p. 373.

${ }^{31}$ Proudhon, De la Justice, III, p. 375.

32 Proudhon, De la Justice, III, p. 375.

${ }^{33}$ On this criticism of Proudhon's idealism, see Proudhon, De la Justice, IV, pp. 317 and 437. On this "a priori" assertion of human consciousness in Proudhon, see III, pp. 339-340. On Proudhon's fascination with this "absolutist" dimension of human consciousness, while at the same time, however, he makes a pitiless critique of it, see III.173.

${ }^{34}$ Proudhon, De la Justice, III, p. 376.

${ }^{35}$ On this point, see Jean Préposiet, Spinoza et la liberté des homes (Paris: Gallimard, 1967), p. 297.

36 "Spinoza himself goes no further. Power is the prerequisite and producer of knowledge, not its effect... it is the condition of the exequatur given to the idea, which by itself is inert, indifferent to its own realization.” Proudhon, De la Justice, III, p. 375.

${ }^{37}$ Proudhon, De la Justice, III, p. 375.

38 "Man is free, he cannot cease to be such, precisely because he is composed; because the law of any compound is to produce a resultant which is its own power." Proudhon, De la Justice, III, p. 409.

39 "Man... is a compound of powers." Pierre-Joseph Proudhon, La Guerre et la Paix (Paris: Rivière, 1861), p. 128. 


\section{DANIEL COLSON}

40 "'The living man is a group." Pierre-Joseph Proudhon, Pbilosophie du progress (Paris: Rivière, 1853), p. 128.

${ }^{41}$ Proudhon, De la Justice, III, pp. 409, 408, 401 and 172.

${ }^{42}$ Proudhon, De la Justice, III, pp. 408-410.

${ }^{43}$ Proudhon, De la Justice, III, p. 409.

${ }^{44}$ Proudhon, De la Justice, III, pp. 411 and 426: "Freedom is the resultant of man's physical, emotional and intellectual faculties; thus, he can neither produce nor precede them; in this sense, he depends on his origins."

${ }^{45}$ On this "intimate sense," this "subjective certainty" or this "phenomenality of ego," see Proudhon, De la Justice, III, pp. 335, 337, 347. On a non-idealist "free will," see p. 409, quoted above, note 38.

${ }^{46}$ Proudhon, De la Justice, III, p. 256: "You feel your me only through the play of the powers which constitute you"; pp. 172-173: "What is it, indeed, that we call a person? And what does this person mean when it says 'Me'?" etc.; and p. 407: "Man, because he is not a simple spontaneity, but a compound of all the spontaneities or powers of nature, enjoys free will."

${ }^{47}$ On the "absolute" as the "principle of illusion and charlatanism," see Proudhon, De la Justice, III, p. 185, and especially 409, where Proudhon shows the opposition between immanence and the illusions of transcendence, between his own concept of "free will" and the abstract and illusory freedom of the devotées of the absolute. After having shown how the "force of collectivity" found a "higher power" in society, where one can speak of the "freedom of the social being." Proudhon continues: "It is this force of collectivity that man indicates when he speaks of his SOUL; it is through this that his ego acquires a reality and leaves the metaphysical clouds, when distinguishing itself from each faculty and from the totality of its faculties, it posits itself as free from all internal and external fatality, sovereign in its autonomous life, as absolute as God, since the divine absolute, being one, i.e. simple, identical, immutable, envelops the world that it produces and that, consequently, it is necessary to; while man, multiple, complex, collective, evolutionary, is an integral part of the world, which he tends to absorb, which constitutes free will."

${ }^{48}$ Proudhon, De la Justice, III, pp. 425 and 407: "It is no longer a question of anything but knowing how... man frees himself, not only from external necessity, but also of the necessity of his own nature, in order to decisively affirm himself as absolute."

${ }^{49}$ Proudhon, De la Justice, III, p. 409.

${ }^{50}$ Proudhon, Pbilosophie du Progrès, p. 64. 


\section{ANARCHIST READINGS OF SPINOZA}

${ }^{51}$ Proudhon, De la Justice, III, p. 403.

${ }^{52}$ Proudhon, De la Justice, III, pp. 433 and 409: "Thus, as we have seen, the industrial groups, as constitutive faculties of the collective being, generate a higher power through their relations with one another, which is the political power, we could say the freedom of the social being."

${ }^{53}$ Proudhon, De la Justice, III, p. 175.

${ }^{54}$ Proudhon, De la Justice, III, p. 409.

55 "Here it is, this revolutionary freedom, accursed for so long because it was not understood, because the key to it was sought in words rather than in things." Proudhon, De la Justice, III, p. 433.

${ }^{56}$ Elisée Reclus, L’homme et la terre (Paris: Librairie Universelle, 1905), Vol. 1, pp. i-ii and iv. On Reclus, see John P. Clark, La pensée sociale d'Elisée Reclus, géographe anarchiste (Paris: Atelier de Création libertaire, 1996).

${ }^{57}$ Etienne Balibar, La crainte des masses, politique et philosophie avant et après Marx (Paris: Galilée, 1977), p. 57.

${ }^{58}$ Alexandre Matheron, Individu et communauté chez Spinoza (Paris: Editions de Minuit, 1969), p. 288.

${ }^{59}$ Antonio Negri, Spinoza subversif (Paris: Kimé, 1992), p. 139.

${ }^{60}$ Antonio Negri, L'anomalie sauvage, puissance et pouvoir chez. Spinoza (Paris: PUF, 1982), pp. 101-102 and 320.

${ }^{61}$ Negri, L'anomalie sauvage, pp. 101-102 and 320, and Spinoza subversive, p. 49.

${ }^{62}$ Negri, L'anomalie sauvage, p. 49.

${ }^{63}$ Negri, L'anomalie sauvage, p. 195 and Spinoza subversive, p. 28.

${ }^{64}$ Matheron, as cited in Negri, L'anomalie sauvage, p. 22.

${ }^{65}$ On this point, see Negri, L'anomalie sauvage, pp. 225-226.

${ }^{66}$ Negri, L'anomalie sauvage, p. 102.

${ }^{67}$ Negri, L'anomalie sauvage, p. 227.

${ }^{68}$ Negri, L'anomalie sauvage, pp. 176 and 158.

${ }^{69}$ Negri, L'anomalie sauvage, p. 209; Spinoza subversive, p. 16;

L'anomalie sauvage, p. 333; Spinoza subversive, p. 16; L'anomalie sauvage, pp. 107 and 211; Spinoza subversif , p. 49; L'anomalie sauvage, p. 209.

${ }^{70}$ Negri, L'anomalie sauvage, pp. 339 and 336; Spinoza subversif , p. 22 and "Démocratie et éternité," in Spinoza: puissance et ontologie, ed. Myriam Revault d'Allonnes and Hadi Rizk (Paris: Kimé, 1994), pp. $141-$ 142.

71 "This point defines the second reason for Spinoza's

contemporaneity. He describes the world as absolute necessity, as presence of necessity. But it is this very presence that is contradictory. Indeed, it 


\section{DANIEL COLSON}

immediately restores necessity to us as contingency, absolute necessity as absolute contingency." Negri, Spinoza subversif , p. 12.

${ }^{72}$ In the sense which "no" "becoming" can claim, as the rest of the quotation shows.

${ }^{73}$ Negri, Spinoza subversif, p. 9.

${ }^{74}$ Negri, Spinoza subversif, p. 10.

${ }^{75}$ Negri, Spinoza subversif , p. 14, L'anomalie sawvage, pp. 288, $155,159,171,175,288,154,161,162,213,202,212,280,321,151$, 298, 308, 182, 259, 184, 182, 239, 242, 259, 184-185, 266, 259, 267, 262, 309, 259, 234, 266, 152, 266 et sq., 234, 262, 197.

${ }^{76}$ Negri, Spinoza subversif , p. 47.

${ }^{77}$ Negri, Spinoza subversif, p. 46.

${ }^{78}$ Negri, Spinoza subversif, p. 51.

${ }^{79}$ Antonio Negri, "L'indignation et le conatus de l'État spinoziste," in Spinoza: puissance et ontologie, ed. M. Revault d'Allonnes and H. Rizk (Paris: Kimé, 1994).

${ }^{80}$ Negri, “L'indignation,” pp. 163-164.

${ }^{81}$ Negri, "L'indignation," p. 159.

${ }^{82}$ Negri, “L'indignation,” p. 164.

${ }^{83}$ For an attempt at explanation, see the assumption of the "double language" developed by Yovel, see Yovel, Spinoza et autres hérétiques, pp. $170 \mathrm{ff}$.

${ }^{84}$ Deleuze, Spinoza philosophie pratique, pp. 146 and 10.

${ }^{85}$ Deleuze, Spinoza philosophie pratique, pp. 10-11. For a more developed approach to what divides and unites the "city" and the "philosopher", see Gilles Deleuze, Spinoza et le problème de l'expression (Paris: Editions de Minuit, 1968), pp. 244 and following.

${ }^{86}$ On this traditional interpretation, see Yovel, Spinoza et autres hérétiques, pp. 172-173.

${ }^{87}$ See the above, part one.

${ }^{88}$ As Negri writes: "Spinoza's philosophy is truly a timeless philosophy: Its time is the future!"' L'anomalie sauvage, p. 64.

${ }^{89}$ Negri, L'anomalie sauvage, pp. 33, 64, 234, 239.

${ }^{90}$ In his foreword, Negri calls this "rereading of Spinoza" a "reading of the past." Negri, L'anomalie sauvage, pp. 32-34).

${ }^{91}$ On the ambiguities of this first genealogy, see Pierre

Macherey, Avec Spinoza: études sur la doctrine et l'bistoire du spinozisme (Paris: PUF, 1992), pp. 246 ff.

${ }^{92}$ In the sense in which one can speak of negative theology.

${ }^{93}$ See above and (for the enigmas and hypostases) Negri, L'anomalie sauvage, pp. 118, 119, 145, 149. 


\section{ANARCHIST READINGS OF SPINOZA}

${ }^{94}$ Negri does not use the word, but the essence of his analysis is built around 1) the concepts of "caesura" (L'anomalie sawvage, pp. 155, 159, 171, 175, Spinoza subversive, p. 14); of "rupture" (Spinoza subversif, pp. 236, 252); of "inversion" (170, 176, 212, 234); of "discontinuity" (244); of "ontological inversion" (154); etc.; and 2) the opposition between the "first" and the "second" Spinoza (39, 60, 67, 320); the "first" and the "second foundation" (99, 213, 214, 264, 266, 291); the "first" and "second layer" (of the Ethics) (103, 139, 153, 162, 176, 198, 212, 213); the "first" and "second drafting" (always of the Ethics) (90, $212,265,294)$; and, especially, the "first" and the "second nature" (170, $187,213,321,325,339)$.

95 "With the general scheme of the project posed, Spinoza proceeds to treat specifically the genealogy of consciousness, the passage from conatus to the subject, in analytical terms." Negri, L'anomalie sauvage, p. 239.

${ }^{96}$ Negri, L'anomalie sauvage, pp. 187, 192 and 254 and following. For the sake of greater convenience we continue to follow Negri here, but this analysis could just as easily, without great modifications, be applied to the major work of Alexandre Matheron (Individu et communauté) where, even more restrictively, he explains how it is only with proposition 29 of book III that Spinoza finally decides "to cut the Gordian knot" in positing, "without demonstrating it," that he is now concerned only with "human nature." "Thereafter, it is only of men that he will speak." See Alexandre Matheron, Individu et communauté, p. 155.

${ }^{97}$ Negri, Spinoza subversif , p. 23; L'anomalie sauvage, pp. 234 and 239. A conception that, in a different form, one finds in Matheron, who, in the foreword that he wrote for Negri's book, explains "how, in this rather artificial natural being that is man, subjectivity is gradually constituted; how the human conatus, become desire, unfolds about him... a human world which is truly a 'second nature." Negri, L'anomalie sauvage, p. 21.

${ }^{98}$ Negri, Spinoza subversif , p. 23; L'anomalie sawvage, p. 244; Spinoza subversif , p. 25; L'anomalie sauvage, p. 243; Spinoza subversif , p. 29. On the reduction of individual human essences, by definition always singular (Ethics II, def. II; Ethics II, prop. 13, lem. 3; Ethics III, prop. 57), to a "nature," "specifically human," that radically separates man from "what is not specifically human," see Matheron, Individu et communauté, pp. $146 \mathrm{ff}$. On the difficulty Matheron encounters in thinking this concept of "human nature," so decisive for the rest of his analysis (as it is for Negri's), which he defines as "something intermediary," see p. 38. 


\section{DANIEL COLSON}

${ }^{99}$ A consequence that Negri himself observes when he notices how the difficulty of giving an "internal unity" to the individual (when one passes from the conatus to the cupiditas) complicates any definition of the multitudo as a political subject, such that "it seems that the multitudo can be a political subject only as an idea of reason or as a product of the imagination." Negri, Spinoza subversif , p. 59.

${ }^{100}$ In fact, as Negri notes, this is doubly indefinite, since the "multitudo" is simultaneously "elusive" in its "concept" and its "materiality." Negri, Spinoza subversif , p. 55.

${ }^{101}$ On the restriction of the vast and supposedly revolutionary political prospects being opened by Spinoza to a few psychological traits transformed into major concepts (animositas, pietas, prudentia), see Spinoza subversif, particularly p. 60, where the inability to give conceptual and material content to the "multitudo" and the contradiction between "the absoluteness of the democratic claim" and "freedom" wind up resolving in the banal concept of "tolerance." In a certain way, the direction taken by Negri is comparable (except for its effects) to that taken by Lenin, who, taking broad considerations of the development of capitalism as his point of departure, ends by entrusting the future of the revolution, as his political legacy, to the psychological traits of Stalin, Trotsky and Bukharin.

102 Peter Arshinov, Le Mouvement makhnoviste (Bélibaste, 1969), p. 388.

103 Arshinov's appeal is inscribed in a libertarian perception that Proudhon, seventy years before the Russian revolution, formulates in these terms: "All theodicy, as I have demonstrated to the point of satiety, is a gangrene for the conscience, every idea of grace a thought of despair. Let us return to ourselves; let us study this Justice that is given to us a priori in the very fact of our existence." Proudhon, Justice, III, p. 347.

${ }^{104}$ Ethics III, preface IV, prop. 4; IV, chap. XXXII; and III, prop. 2, scol.: "No one has hitherto laid down the limits to the powers of the body, that is, no one has as yet been taught by experience what the body can accomplish."

${ }^{105}$ On this point, see Pierre-Francois Moreau, Spinoza: l'expérience et l'éternité (Paris: PUF, 1994), p. 379 ff.; Matheron, Individu et communauté, pp. 83-85; Balibar, La crainte des masses, p. 87 and following; and Negri himself when, a little discouraged, he observes, concerning book IV, how "we can feel the weight of the seventeenth-century moral casuistries" (L'anomalie samvage, p. 262).

${ }^{106}$ Deleuze, Spinoza philosophie pratique, pp. 10-11. 


\section{ANARCHIST READINGS OF SPINOZA}

${ }^{107}$ Without entering into a detailed analysis, let us only state that to Negri's quasi-chronological reading, transforming, as one saw, the thought of Spinoza into a kind of long gestation of being, is opposed, doubly, Deleuze's reading, which, while taking account of the ruptures and events in Spinoza's life and thought, shows how the Ethics must initially be read in a vertical way (in the form of plateaus, propositions, scholiums, the fifth book "coextensive" with all the others), and especially how the importance of common notions demands a reverse reading of the Ethics, beginning with an immediate "experimenting," an "art" of "organizing good encounters." See Deleuze, Spinoza philosophie pratique, chapter 5; Deleuze, Spinoza et le problème de l'expression, chapter 17; and "Spinoza et les trois "éthiques"” in Critique et Clinique (Paris: Éditions de Minuit, 1993). In Negri’s analysis, the "common notions" play only an extremely marginal role, constituting merely a "logical possibility," an instrument of "logical communication,” a "purely formal solution.” See Negri, L'anomalie sauvage, pp. 183-184 and 258.

${ }^{108}$ Negri, L'anomalie sauvage, pp. 339, 156 and 335:

"Emancipation is therefore the organization of the infinite....The disutopia is the specific form of the organization of the infinite."

${ }^{109}$ Macherey, Avec Spinoza, p. 246.

${ }^{110}$ Bernard Rousset, "Le réalisme spinoziste de la durée," in l'Espace et le Temps (Paris: Vrin, 1991), pp. 176 ff.; and, likewise, "Les implications de l'identité spinoziste," in Spinoza: puissance et ontologie, ed. Revault d'Allonnes and Rizk (Paris: Kimé, 1994).

111 "Spinoza defines the continual variations of existence by duration." "Duration is said, then, not of the relations themselves, but of the way in which actual parts are subsumed under this or that relation." Deleuze, Spinoza philosophie pratique, pp. 57 and 110. Spinozist duration is multiple, since it is tied to the variations of the power to act and suffer proper to each existing body which is always itself the "expression" of a "singular essence." See Deleuze Spinoza et le problème de l'expression, p. 209.

112 On the concept of the "possible" in Spinoza, see Rousset, "Les implications," p. 12 (see note 110).

113 On the Spinozist critique of the scholastic "possible," see Deleuze, Spinoza philosophie pratique, p. 89 and Spinoza et le problème de l'expression, p. 194.

${ }^{114}$ Deleuze, Spinoza philosophie pratique, pp. 19 and 14.

${ }^{115}$ Rousset, "Le réalisme," p. 177; and Deleuze, Spinoza philosophie pratique, p. 171. 


\section{DANIEL COLSON}

${ }^{116}$ Rousset, "Implications," p. 14: "to be really possible is not to be almost real, but to be indeed real: to be in power is to be in act."

${ }^{117}$ On this point, see Jean Milet, Gabriel Tarde et la philosophie de l'bistoire (Paris: Vrin, 1970, p. 154; on its intersection with a "libertarian" reading of Spinoza, see Deleuze, Spinoza philosophie pratique, pp. 124 and 110.

${ }^{118}$ Gilbert Simondon, L'individuation psychique et collective (Paris: Aubier, 1989), pp. 215, 194 and 196.

${ }^{119}$ Balibar, La crainte des masses, p. 87 ff.; and Deleuze, Spinoza philosophie pratique, p. 166: "Every reader of Spinoza knows that for him bodies and minds are not substances or subjects, but modes."

${ }^{120}$ Balibar has the art of resolving difficulties by serenely affirming and including two contradictory things in the same concept, after the manner of his master Lenin. He speaks, for example, without batting an eyelash, of "obedience/nonobedience" or of the "state/ nonstate" (La crainte des masses, p. 63); it is true that in his time a famous anarchist review, Noir et Rouge, had finished, in a very similar way but with the excuse of an authentic theoretical despair, by speaking of the "non-group group". In what concerns us here, Balibar is satisfied to observe how "In reality, without the idea of individuality (that is, of the stability of a composite) disappearing, without which there would be neither desire nor force (conatus), it is the process itself, the affective network cutting across each individual, which soon becomes the true 'object' (or the true 'subject')" (p. 89). Balibar's inability to make "individuality" disappear (but without explaining why) suffices to demonstrate how the narrow, closed field of the affective network is unable to account for reality ("actually") and in the way in which the human existence is in this reality and can transform it.

${ }^{121}$ See Ethics III, preface, and IV, prop. 4: "It is impossible, that man should not be a part of Nature, or that he should be capable of undergoing no changes, save such as can be understood through his nature only as their adequate cause".

${ }^{122}$ Ethics II, m. 13, scol. On the idea of "agreement," see Deleuze, Spinoza philosophie pratique, p. 47.

${ }^{123}$ Deleuze, Spinoza philosophie pratique, p. 168. On the concrete implications of such a conception of things, cf. the slogan of May '68, "the police are with us!" or the experiment that anyone could make as to what "becomes" of an anarchist who is given or accepts the badge of some order of service (not to speak of a Kalashnikov).

${ }^{124}$ Negri, L'anomalie sauvage, p. 11. 


\section{ANARCHIST READINGS OF SPINOZA}

${ }^{125}$ As Balibar notes, the concept of multitude is completely lacking from the Ethics, present in the Theological-Political Treatise but generally in a pejorative way; and it is only with the Political Treatise that it acquires a definitely marked political significance. See Balibar, $L a$ crainte des masses, pp. $67 \mathrm{ff}$.

${ }^{126}$ See above.

${ }^{127}$ On the quantitative (and nonnumerical) character of the composition of a mode, on the idea of an infinity of infinite sets and, worse (Deleuze, like Spinoza, being always ready to worsen his case on the battlefield of applied mathematics), the idea of "an infinity that...can be more or less large" (according to the power of the modes), see Deleuze, Spinoza et le problème de l'expression, p. $183 \mathrm{ff}$. Deleuze's remark might lead one to think that the "multitude" characterizes only the "body" and not the soul, which Deleuze only introduces between brackets (and only twice). However, for Deleuze, the very multiplicity or multitude of the "elements," external to one another, has its counterpart in the soul, insofar as "extension" is not a privilege of the extended and insofar as thought itself has "extensive modal parts, ideas that correspond to the simplest bodies." Deleuze, Spinoza et le problème de l'expression, p. 174. On this point, see also Renée Bouveresse, Spinoza et Leibniz, l'idée d'animisme universel (Paris: Vrin, 1992), p. $67 \mathrm{ff}$. This problem of the relationship between body and soul (the problematic of the 17 th century) allows me to indicate that I am entirely willing to expose myself, in the whole of this text, to the reproach of "naturalizing" Spinoza and thus of naturalizing the libertarian reading of this philosopher. No doubt the radical materialism of anarchism (in particular in Bakunin) also authorizes me to do so, and the current context makes this insistence necessary. Nonetheless, without demonstrating it here, I would like to say that this "naturalization" (perhaps extreme and disturbing for some), contrary to appearances, leaves plenty of room for "conscience", "thought," and, of course, "reason."

${ }^{128}$ Matheron, Individu et communauté, p. 147: "There are thus elementary biological communities which, because they are based on what, in man, is not specifically human, can also include animals and things: a community, for example, between the peasant, his family, his animals, his field and his idols. But authentic sociability, which has an altogether different origin, could never emerge from them."

${ }^{129}$ Deleuze, Spinoza philosophie pratique, p. 164.

${ }^{130}$ Deleuze, Spinoza philosophie pratique, p. 167.

${ }^{131}$ Deleuze, Spinoza philosophie pratique, esp. p. 155. 


\section{DANIEL COLSON}

${ }_{132}$ Bakunin, Oeuvres complètes, VIII, p. 201 (see note 3).

${ }^{133}$ Deleuze, Spinoza philosophie pratique, p. 58. On this nonmetaphorical idea of "model", a thought closer to that of mode or modality, cf. Spinoza et le problème de l'expression, p. 236.

${ }^{134}$ Deleuze, Spinoza philosophie pratique, pp. 129 and 156.

${ }^{135}$ Deleuze, Spinoza philosophie pratique, p. 58.

${ }^{136}$ Deleuze, Spinoza philosophie pratique, p. 114.

${ }^{137}$ Proudhon, Justice, III, p. 71.

${ }^{138}$ On this point, see Deleuze, Critique et Clinique, p. 180 and following.

${ }^{139}$ On the bond, in Spinoza, between "rights," "ethics" and the physical and "biological" model which is used to think them, see Deleuze, Spinoza et le problème de l'expression, p. 236.

140 "At the deepest level of the obscure mixture of bodies,"

the site of a "combat between servitudes and emancipations." Deleuze, Critique et Clinique, p. 182.

${ }^{141}$ See Deleuze, Spinoza philosophie pratique, pp. 169 and 161:

"The common notions are an Art, the art of the Ethics itself: organizing good encounters, composing actual relations, forming powers, experimenting."

${ }^{142}$ Proudhon, Justice, III, pp. 69, 71-73.

143 "What can we expect from man...? - Only one thing, acts"; "reflection, and consequently the idea, is born in man from action, not action from reflection," Proudhon, Justice, III, pp. 72 and 71.

${ }^{144}$ Proudhon, Justice, III, p. 89.

${ }^{145}$ Proudhon, Justice, III, pp. 79 and 73. De la Justice is constructed around the concept of "balance," and it is from this point of view that the "relations" and "accords" proper to labor and industry are thought in terms of "equation," "equality," "agreement," etc. But the Proudhonian concept of "composition," also so important for thinking the various forms of individualities, arises, as in the Spinoza of Deleuze, from a "chemical" model which allows Proudhon besides, along with other conceptual models, to depart from the single "plane" of labor, as indicated by a passage in De la création de l'ordre on the concept of "composition": "Thus labor, a manifestation of human intelligence and activity, follows the laws of thought and nature; it is not divided, if I dare to employ this chemical language, into its integral pieces, it is duplicated in its constituent species." Pierre Joseph Proudhon, De la création de l'ordre dans l'bumanité (Paris: Rivière, 1927), p. 329.

${ }^{146}$ Deleuze, Critique et Clinique, p. 179. 
ANARCHIST READINGS OF SPINOZA

${ }^{147}$ See Proudhon, Justice, II, pp. 15, 79 and 127.

${ }^{148}$ Deleuze, Spinoza philosophie pratique, p. 144.

${ }^{149}$ Deleuze, Spinoza philosophie pratique, p. 169.

${ }^{150}$ Deleuze, Spinoza et le problème de l'expression, pp. 245-247.

${ }^{151}$ Deleuze, Spinoza et le problème de l'expression, p. 244.

${ }^{152}$ Deleuze, Spinoza philosophie pratique, p. 171. 